$3 / 4$ hours, around yard $3 / 4$ hour, temp. $10^{\circ}$ $22^{\circ}$, sunny, wind brisk, 8 inches of snow; 11 species, 422 individuals. (Add: Prairie Falcon, 1, Dec. 17; Sharp-tailed Grouse, 5, Dec. 20 and 6, Dec. 30; Great Horned Owl, 1, Dec. 27, 28; Northern Shrike, 1, Dec. 30). - Allan Bogdan, Flossie Bogdan (compiler), Larry Bogdan, Nick Bogdan.

37. SQUAW RAPIDS. Dec. 26; 7 hours in field, temp. $25^{\circ}$, overcast, no wind; 20 species, 1134 individuals. - Gladys and Stan Riome.

38. TUBEROSE-KYLE. Dec. 26; 64 miles by car and $1-1 / 2$ miles on foot in 3 hours, temp. $18^{\circ}$, wind SE $8 \mathrm{mph}$, clear; 3 species, 45 individuals. - Cliff Matthews.

39. VAL MARIE. Dec. 31; 50 miles by car and 2 miles on foot, temp. $28^{\circ}$, sunny, calm, 2 inches of snow; 4 species, 37 individuals. (Add: Prairie Falcon, 1, Dec. 24; Gray Partridge, 3, Dec. 26; Snowy Owl, 1, Dec. 29; Common Redpoll, 3, Dec. 24; Snow Bunting, 100, Dec. 26). - J. David Chandler.

40. WAUCHOPE. Dec. $24 ; 33-1 / 2$ miles $(53.6 \mathrm{~km})$ by car in 3 hours, 3 miles $(4.8$ $\mathrm{km}$ ) on foot in 3 hours, and watching feeder throughout day, temp. $-4^{\circ} \mathrm{F}$ to $22^{\circ} \mathrm{F}\left(-20^{\circ} \mathrm{C}\right.$ to $-6^{\circ} \mathrm{C}$ ), wind $\mathrm{SW} 3-4 \mathrm{mph}(4-5 \mathrm{~km})$ in P.M., overcast and heavy fog in A.M., clearing mid morning, then partial cloud cover, snow 10 inches $(28 \mathrm{~cm}) ; 13$ species, 562 individuals. (Add: Sharp-tailed Grouse, 4, Dec. 23; Ring-necked Pheasant, 1, Dec. 25; Evening Grosbeak, 11, Dec. 30). - Dale Hjertaas (compiler), Elinor Hjertaas, Warren Hjertaas.

41. WELLINGTON LAKE $\left(59^{\circ} 38^{\prime} \mathrm{N} 109^{\circ}\right.$ $02^{\prime}$ W) . Dec. 29 ; temp. $19^{\circ}$, calm: 8 species, 39 individuals. - Edith and Roy Middleton.

42. WHITE BEAR. Dec. 30; 5-1/2 miles by car, 3 miles on foot, temp. $30^{\circ}$, light west wind, sunny, light snow cover: 5 species, 25 individuals. (Add: Mourning Dove, 1, Dec. 26). - Carl and Peter Bischoff, Oran Cates, Leroy Clark, Douglas Gunn, Gary, Laine and Sig Jordheim, David Lowe, Dan Schuler (White Bear Conservation Club).

43. WHITE BEECH-ARRAN. Dec. $25 ; 65$ miles by car and at feeding station, 9 species, 92 individuals. - Margaret Hutchinson, Mr. and Mrs. L. A. Wotherspoon.

44. YORKTON. Dec. 29; 76 miles by car and 2 miles on foot, temp. $6^{\circ}$, sunny, wind $S$ $6 \mathrm{mph}, 5$ inches of snow; 9 species, 689 individuals. - Margaret Bromley (compiler), Lorne Lepp, Larry Morgotch, Phil Pawluck, Harold Wilkinson.

\section{FORT SMITH, N.W.T., CHRISTMAS BIRD COUNT}

by ERNIE KUYT*

Date: December 28, 1974.

Weather: Sunny and clear; tem perature $-18^{\circ} \mathrm{F}$; light wind; sno depth about $27 \mathrm{~cm}$; daylight 9:00 a.m - 4:00 p.m.

Routes covered: Fort Smith to Foll Holes road intersection; - Fort Smit along Pine Lake road to Salt Rive Fort Smith to Mountain Portage 0 cross-country skis. Total $80+48$ $12=140 \mathrm{~km}$. from $10-2$ p.m.

Birds seen: Raven 141, Gray Jay Rock Dove 45, Spruce Grouse Sharp-tailed grouse 8, Willow Pta migan 1, Hairy Woodpecker 1, Down Woodpecker 1, Pine Grosbeak 21 t Hoary Redpoll 23, Black-cappe Chickadee 4, House Sparrow 4.

Contributors: Elsie, Ernie, Pamel: Jonathan Kuyt; Linda and Da Graham; Hilah, Norman, David Sim mons: Debbie, Rex, Billie, Coupland: Alan Lee and Jim Mills.

*Box 508

Fort Smith, N.W.T.

\section{WATCH FOR MARKED COWBIRDS}

Over 7,100 Brown-headed Cowbirds were banded and colour marked in west-central Kansas during 1974 as an aid in studying their movements and, hopefully, to determine their places of origin Birds were marked with red, yellou or green plastic leg streamers. Fal and winter observations revealed 27 individuals from 10 locations it Kansas, Oklahoma, Texas and Mexico. However, data from spring and summer movements ar needed. Observers can help b. reporting location and date o sighting, sex of bird, and colour o leg streamer to Richard A. Hill Department of Biology, Fort Hay Kansas State College, Hays, Kansa 67601 . 